\title{
ANTI METAFISIKA DALAM EPSITEMOLOGI IMMANUEL KANT DAN KEMUNGKINAN AGAMA SEBAGAI JALAN
}

\author{
Muhammad Yunus
}

STAI Bumi Silampari Lubuklinggau muhammadyunustalban@gmail.com

\begin{tabular}{ll}
\hline & Abstrak \\
\hline Article History & The purpose of this study is to explore \\
Received $: 21-12-2020$ & the underpinnings of Kant's doubts \\
Revised $: 24-12-2020$ & about metaphysics and its implications \\
Accepted $: 28-12-2020$ & for epistemological problems. Some of \\
\hline Keywords: & the questions that will be answered in \\
Kant Metaphysics, & this study (1) What is the basis for \\
Epistemology & Kant's doubts about metaphysical \\
& problems? (2) what are the \\
& implications of Kant's doubts on \\
& metaphysical questions? (3) How does \\
& religion provide answers to these \\
& answers? This research uses literature \\
& sources such as books, journals and \\
& relevant research reports. The \\
& analytical method uses hermeneutics \\
& which includes elements of description \\
& and interpretation. The result of this \\
& research is that Kant believes that \\
& every scientific decision comes from \\
& experience and reason. Meanwhile, \\
& nomena is a reality beyond the \\
boundaries of knowledge. This view of \\
Kant has implications for the search \\
for new methods of approaching \\
metaphysics. Religion is an alternative \\
which needs to be considered as a \\
method of understanding the nominal \\
reality that Kant doubts. Religion has \\
become a kind of epistemology for \\
metaphysical problems. \\
\hline
\end{tabular}




\section{Pendahuluan}

Metafisika merupakan cabang filsafat yang membahas tentang hakikat realitas, atau disebut juga teori realitas. Dalam pohon filsafat, metafisika menempati posisi yang paling dasar yaitu akar (Palmquist, 2007). Metafisika berbeda dengan kebanyakan ilmu yang ada,yang hanya menjangkau objek-objek indrawi. Metafisika berusaha menggapai realitas terdalam dari objek yang dipikirkan. Memang, metafisika tidak pernah tuntas menggambarkan pengalaman manusia, mengingat pengalaman manusia itu kaya dan dalam. Sekalipun itu, kebutuhan akan metafisika merupakan hasrat manusia, yang tak mau jatuh dalam kekinian dan terbelenggu oleh kondisi dan situasi kekiniannya itu (Bagus, 1991).

Dalam sejarah filsafat, usaha untuk menggapai esensi semesta raya telah dimulai oleh para filusuf Yunani kuno. Para filusuf alam semisal Thales,meyakini bahwa air merupakan asal mula semesta. Demikian pula dengan para filusuf sezamannya seperti Anaximes, Anaximandros, Democritos, Zeno hingga Aristoteles yang juga menelaah sebab-sebab dasar yang ada menurut pendapat mereka masing-masing. Tidak hanya itu, para filusufpun, telah berusaha menyusun metode untuk mendapatkan pengakuan universal tentang metafisika. Plato dengan metode dialektik, Aristoteles dengan silogismenya, Descartes dengan metode skeptis, semuanya tiada lain sebagai ikhtiar meraih kebenaran hakiki (Sumaryono, 1999). Usaha pencarian tiada henti ini, rupanya telah membuat sebagian pemikir menolak adanya metode dalam metafisika, dengan alasan bahwa metode menentukan wajah kenyataan. Metode umumya digunakan sains untuk menelaah objek tertentu, sementara dalam metafisika, realitas yang menyeluruh dan dalam tak mungkin digapai oleh metode. (Snijder, 2009).

Aktivitas penyelidikan yang terus berlangsung itu, ternyata juga menyebabkan keraguan akan kemampuan manusia menerangkan metafisika. Keraguan semacam itu terlihat pada skeptisisme, empirisme, matrealisme, positivisme dan para filsafat analitik tak terkecuali dua filusuf jerman yaitu David Hume dan Immanuel Kant (Bagus, 1991).

Nama yang disebut terakhir ini (Kant), adalah seorang filusuf besar yang berjasa besar mendamaikan pertentangan antara dua mazhab filsafat yaitu empirisme dan rasionalisme. Berkat Kant pertentangan antara plato dan aristoteles dapat diatasi. Keduanya 
menurut Kant berat sebelah. Kant menyatakan bahwa Plato benar ketika ia mengatakan bahwa ide adalah relaitas sesungguhnya, karena saat mengatakannya ia merujuk pada aspek metafisisnya, demikian pula bahwa Aristoteles benar saat mengatakan bahwa realitas empirismerupakan esensi, karena ia mengacu pada sisi empirisnya.(Palmquist, 2007).

Kant meski dipersepsikan sebagai seorang yang anti metafisika, namun pada akhirnya dia merumuskan adanya dua realitas yaitu,fenomena dan nomena. Dua rumusan kenyataan ala Kant ini menjadi bukti bahwa sebenarnya Kant bukanlah anti metafisika. Namun lebih dimaknai sebagai pengakuan terhadapketerbatasan nalar untuk menggapainya (Adian, 2012). Pengakuan akan kebebalan Kant ini mengimpilkasikan akan perlunya cara lain dalam mendekati metafisika.

Dalam konteks pesimisme Kant akan metafisika inilah penelitian ini dilakukan. Beberapa pertanyaan yang akan dijawab dalam penelitian ini adalah sebagai berikut: (1)apa dasar keraguan Kant terhadap persoalan metafisika?(2) apa implikasi pandangan Kant tersebut tehadap metode pengungkapan realitas metafisik (epistemology)? (3) adakah jalan alternatif yang dapat ditempuh untuk mengatasi persoalan metafisika yang ditolak Kant?, (4) jika ada, apa dan bagaimana gambaran prihal jalan itu?

\section{Metode Penelitian}

Penelitian ini menggunakan sumber-sumber kepustakaan seperti buku-buku, jurnal dan laporan-laporan penelitian yang relevan. Metode analisis menggunakan hermeneutik yang meliputi unsur-unsur deskripsi dan interpretasi.

\section{Pembahasan}

\section{Dasar Keraguan Kant pada Metafisika}

Titik tolak sistem pemikiran filosofis Kant (1724-1804) adalah keyakinan akan realitas benda-benda yang dalam lubuknya masing-masing tak diketahui. Hal ini karena Kant dengan metode kritik transendennya telah menetapkan tapal batas tentang apa yang dapat dan tidak dapat dicapai oleh akal manusia (Palmquist, 2007). Kant menyelidiki relasi pikiran dengan objeknya (Adian, 2012). Atas dasar ini ia kemudian berkeyakinan bahwa permasalahan metafisika 
adalah persoalan hubungan antara pikiran dengan realitas, oleh karena itu metafisika bersifat reflektif. Karena bersifat reflektif, maka rasio harus memeriksa dirinya sendiri (Palmquist, 2007). Pemeriksaan terhadap kinereja rasio inilah yang menjadi tujuannya dalam penyusunan buku "Critique of Pure Reason" atau krtik akal murni.

Kritik akal murni yang dirumuskan Kant mengawali pembahasan tentang pengetahuan yang dibaginya menjadi beberapa tipe, yaitu pengetahuan analitis apriori dan sintesis aposteriori. Karakteristik dari pengetahuan analitik apriori adalah pengetahuan yang dilengkapi dimensi universal. Namun pengetahuan ini bersipat tautologis dan tidak menimbulkan suatu pengetahuan baru. Sebaliknya pengetahuan sintesis apriori merupakan pengetahuan yang diperoleh melalui pengalaman dimana predikat kehilangan aspek universalitasnya.

Menurut Kant masih ada satu jenis putusan lagi yang disebutnya dengan istilah sintesis apriori. Pengetahuan ini memiliki ciri universal namun tidak bersifat tautologis. Pengetahuan ini dibentuk dari unsur forma dan materi. Forma merupakan unsur intelek yang lepas dari pengalaman, sementara materi merupakan aspek luar intelek atau objek empiris. Dengan demikian,pengetahuan sintesis apriori bersifat universal namun juga sah dalam dunia pengalaman.

Pengetahuan sintesis apriori ini akan tercapai hanya jika terjadi apa yang disebut dengan rovolusi kovernikan (sebuah perubahan cara pandang terhadap teori heliocentris). Pada revolusi epistemologi Kant, subjek yang semula mengarahkan diri pada objek, menjadi berbalik yaitu objeklah yang mengarahkan diri pada subjek atau pengamat. Atas dasar penelaahan diri subjek, maka Kant memisahkan pengetahuan dasDing an sich (nomena) dengan pengetahuan-penegatahuan empirik atau fenomena. (Muthmainnah, 2018). Dunia fenomena adalah dunia dimana ia dapat diketahui oleh manusia. Sebaliknya dunia nomena adalah dunia dimana kenyataan tersebut diluar tapal batas pengetahuan, sehingga mustahil mencapainya (Mulyono Slamet Subekti, 2016).

Dua jenis kenyataan itu telah membentukcara pandangan Kant terhadap metafisika. Iamembagi metafisika menjadi dua jenis yaitu metafisika pengalaman dan metafisika transenden. Metafiska pengalaman adalah mungkin untuk diketahui oleh manusia, 
sebaliknya metafisika transenden adalah sesuatu yang mustahil (Reza, 2010).

Satu hal yang perlu dicatat dari Kant adalah bahwa meski ia ragu akan kemungkinan nalar untuk mengetahui realitas benda dalam dirinya sendiri (das ding an sich), namun bukan berarti Kant menolak metafisika secara totalitas, ia sama sekali tidak menafikan ide-ide seperti teologi, psikologi dan kosmologi, hanya saja ide-ide itu ditempatkannya pada dunia nomena yang tidak diketahui (Adian, 2012).

\section{Implikasi Keraguan Metafisika Kant terhadap Metode Metafisika.}

Pasca Kant, metafisika telah menjadi perbincangan bagi para filusuf jerman, terutama mereka yang menganut mazhab idealisme. Mereka adalah Fitche, Scheling, dan Hegel. Mereka telah mengulang kembali pandangan Plato tentang ide abadi, meskipun dengan ungkapan yang berbeda-beda. Realitas sebenarnya bagi mereka adalah roh absolut, indentitas absolut dan aku absolut(Mulyono Slamet Subekti, 2016). Selain itu, anti metafisika pasca Kant terwujud dalam pemikiran Heidegger (1889-1976). Heidegger meruntuhkan tradisi metafisika barat yang mengklaim bahwa realitas sebenarnya dibalik yang nampak, dan menganggap manusia mampu mencapainya. Menurut Heidegger para metafisikus telah mengalami apa yang disebutnya dengan "kelupaan ada”. Umumnya para filusuf menyamakan antara ada dan adaan(being dan beings). Ada bagi Heidegger tidak merujuk pada entitas-entitas tertentu sehingga ia tidak bisa diterangkan dengan deskripsi kategori-kategori. Heidegger menolak metafisika kehadiran yang menganggap bahwa ego dapat mencapai posisi sudut pandang Tuhan. Subjek menurut Heidegger tidak akan pernah meraih pemahaman total (Adian, 2012).

Dari beberapa keraguan tentang kemungkinan mencapai metafisika pada ranah epistemology, membawa sebuah pertanyaan tertentu yaitu apa implikasi keraguan tersebut bagi metode penyelidikan metafisika?. Jawabannya tentu saja mengharuskan adanya alternatif lain dalam penyelidikannya. Sebab jika tidak, persoalan metafisika menjadi mengambang, dan para metafisikus akan terperangkap pada semacam kegelisahan curiousity akibat ketiadaan jalan menempuhnya, ini tentu saja bukan sebuah problem 
solving. Lagi pula persoalan metafisika telah menjadi perhatian sejak filusuf Yunani hinggah hari ini. Proyek yang telah memakan waktu yang panjang tersebut tidak boleh dibiarkan menggantung tanpa jawaban. Harus ada sebuah metode yang memungkinkan manusia dapat menerima kenyataan metafisika, entah itu berupa metode sains, mitos ataupun semacamnya.

\section{KemungkinanAgama sebagaiJalan Menuju Realitas Metafisik.}

Menurut Thomas sebagaimana dikutif Lorens Bagus dalam bukunya "Metafisika" menyatakan bahwa metafisika pada dasarnya terarah pada sang Ilahi, sebagai kesimpulan akhir dari refleksi filosofis (Bagus, 1991). Allah adalah yang pertama ada, dan sebab segala yang ada. Ia tidak disebabkan oleh apapun, sebab bila sebab itu disebabkan, maka sebab itu sama dengan yang lain, dan kita akan terjebak pada rangkaian sebab akibat yang tak berkesudahan, hal ini adalah mustahil. Dari sebuah wujud pastilah berawal dari ketiadaan yang membutuhkan sebab pertama (causa prima). Sebab inilah yang dimaksudkan oleh Thomas dengan Sang Ilahi atau dalam bahasa agama disebut Tuhan.

Keterarahan kepada Tuhan dalam refleksi filosofis ini, tidak dimaknai sebagai akhir perjalanan filsafat, melainkan pengakuan keraguan atas kapasitas panca indra dan rasio sebagai metodenya, sehingga menuntun kepada jalan baru dalam mendekati metafisika, yaitu dengan cara berpaling kepada agama.

Agama bila dilihat dari proses terbentuknya, maka akan tampak bahwa tidaklah benar bila agama dikatakan sebagai sesuatu yang tidak melibatkan penalaran dan tanpa ikhtiar filosofis manusia. Pencerahan yang didapat oleh para nabi sebagai utusan Tuhan, ternyata juga diawali dengan aktivitas kontemplasi. Muhammad merenung di gua hira (S. Nasution, 2013), Ibrahim berkontemplasi tentang bulan dan matahari sebelum menerima Tuhan Allah, begitu pulapengembaraan Budha Gautama yang akhirnya pencerahan diperoleh dibawah pohon Bodhi(Harun Hadiwijono, 2008). Kenyataan ini menunjukkan bahwa agama juga dimaknai sebagai pengetahuan tertinggi yang juga dicapai melalui proses filosofis, dimana kontemplasi adalah metodenya. Agama yang dalam hal ini adalah wahyu, tidak jauh berbeda dengan intuisi sebagaimana yang diuraikan Bergson dan Iqbal, yaitu berupa pengetahuan langsung, hanya saja, intuisi yang dimiliki oleh para nabi terdokumentasi dalam 
bentuk kitab suci dan disampaikan secara mutawatir, sehingga menjadi epistemologitersendiri bagi pemeluknya.

Agama adalah hasil pengalaman keagamaan manusia. Pengalaman keagamaan ini terdiri dari dua tipe. Pertama pengalaman keagamaan yang mengangkat seseorang menjadi nabi. Kedua pengalaman keagamaan yang tidakmengangkat seseorang menjadi nabi. Pengalaman keagamaan menurut Sorosh merupakan pertemuan antara seseorang dengan Tuhan sebagai zat transenden. Sebagai pengalaman keagamaan, wahyulah yang mengikuti nabi bukan sebaliknya (Wijaya, 2016).

Pada agama-agama Abrahamik, agama didasari oleh adanya wahyu Tuhan yang diberikan kepada manusia pilihan. Dengan demikian, wahyu mempunyai kedudukan terpenting dalam agama. Permasalahan yang muncul adalah apakah wahyu itu mungkin?. Menjawab permasalahan ini, Harun Nasution dan beberapa peneliti fenomena agama menguraikan kemungkinan-kemungkinan terjadinya pewahyuan sebagaimana uraian berikut: Pertama, dalam filsafat, Tuhan disebut Mind atau akal. Sebagai akal Ia dapat berkomunikasi dengan manusia yang juga mempunyai akal. Jika komunikasi antara Tuhan dan manusia dapat diterima, maka pewahyuan juga bukan suatu yang mustahil, sehingga memungkinkan pewahyuan terjadi $(\mathrm{H}$. Nasution, 1975). Kedua, meskipun proses pengalaman wahyu bersifat personal dan beragam, namun telah berhasil mengubah cara manusia melihat realitas dan membuat kualitas kehidupan manusia lebih berharga. Ketiga, Sains bukanlah satu-satunya jalan menuju kebenaran. Wahyu merupakan jalan personal yang dicapai melalui pengalaman batin. Keempat, konten wahyu memang ditangkap secara berbeda-beda namun mempunyai inti yang sama, yaitu berisi nilainilai yang mengajak manusia menuju pada nilai yang lebih tinggi dan kematangan spiritual. Kelima, pengakuan sains bahwa alam semesta sangat mungkin muncul dari intelegensi kreatif. Kemungkinan ini membuka peluang bahwa substansi kreatif itu memang ada, dan menyatakan diriNya melalui wahyu. Akhirnya dengan mengikuti anjuran Paul F. Knitter, kita perlu memandang wahyu agama-agama sebagai sebuah peta wilayah yang menuntun kita menuju suatu tempat yang kita tuju. Namun peta itu bukanlah tempat itu sendiri, begitupun dengan agama-agama, mereka bukanlah realitas Tuhan itusendiri melainkan jalan menuju Realitas yang didambakan. 
Pernyataan Max Muller tak kalah penting direnungkan, bahwa agama pada umumnya merupakan sebuah usaha untuk mengerti segala sesuatu yang tak terpahami, dan mengungkapkan hal yang tak ternyatakan, agama adalah keinginan untuk mencapai sesuatu yang tak terbatas (Bartolomeus Samho, 2019).

Beberapa hal yang juga perlu ditegaskan dalam hal pengetahun agama yaitu, persoalan bukti-bukti pengetahuan agama. Dalam hal ini tidak benar bila agama hanya berdasarkan wahyu semata. Pengetahuan agama juga berdasarkan pada bukti-bukti lain, seperti bukti historis, argumentasi rasional dan pengalamanpengalaman pribadi.

Dalam ilmu pengetahuan misalnya kita seringkali mendapat figur-figur saintis seperti Aguste Comte, Covernicus, dan Isac Newton. Kita sama sekali tidak pernah berjumpa dengan para ilmuwan itu, mereka diketahui hanya melalui tulisan dan keteranganketeran sejarah yang sampai hari ini tak ada satupun yang membantah akan adanya tokoh-tokoh itu. Hal yang sama juga berlaku pada agama, pengetahuan tentang Budha, nabi Musa, Isa dan nabi Muhammad diperoleh dari tradisi yang diperkuat dengan bukti-bukti historis. Mengenai nabi Muhammad misalnya, sampai saat ini belum ada satupun yang mengatakan bahwa figur ini merupakan tokoh fiktif layaknya dongeng pengantar tidur. Sejarahnya jelas, kitab suci yang ditinggalkannya ada, kata-katannya dicatat dengan rentetan periwayatan yang jelas. Dengan demikian kalau ada tuduhan bahwa pengetahuan agama hanya berdasar pada tradisi, maka dalam ilmu pengetahuan pun juga bersandar pada tradisi sebagaimana terdapat dalam filsafat, sejarah dan ilmu-ilmu lainnya (H. Nasution, 1975).

Pengetahuan agama juga diperkuat dengan argumentasi rasional, terutama tentang wujud Tuhan. Bukankah dalam refleksi filosofis Aristoteles telah sampai pada penggerak pertama yang menjadi causa prima dari segala realitas. Immnuael Kant sampai pada Tuhan dengan argument moral, Thomas dengan argument ontology. Semua argumentasi rasional itu juga memperkuat pengeatahuan agama.

Pengetahuan agama juga diperkuat dengan pengalampengalamn pribadi. Bila dalam sains menggunakan eksperimen sebagai metodenya, maka dalam agama juga ada experimenexperimen pribadi terutama dalam persoalan ketuhanan. Pengalaman ini sering diungkapkan oleh para mistiskus. Pengalaman ini tidak 
hanya terdapat pada satu agama saja, namun juga terdapat pada agama-agama besar disemesta raya ini. Integritas moral mereka yang terpercaya membuat kita sulit menolak keterangan-keterangan mereka. Bila merujuk pada jumlah para pelaku eksperimen baik dalam sains maupun pada pengalaman pribadi, terlihat bahwa hanya segelintir orang saja yang berperan sebagai pelaku eksperimen. Jadi tidak beralasan untuk menolak pengalam pribadi hanya karena sedikitnya orang yang mengalaminya.

Keberagamaan sendiri menurut Iqbal, adalah sebuah evolusi yang terdiri dari tiga tahap.Pertama tahap iman, dimana manusia menerima keseluruhan doktrin tanpa protes sedikitpun. Ajaran-ajaran agama pada level ini dianggap sebabagai sesuatu yang telah diberikan dan diterima dengan penuh ketaatan. Level kedua dari agama menurut Iqbal adalah tahap refleksi, tahap ini merupakan upaya memahami makna keseluruhan ajaran agama. Level ketiga adalah tahap penemuan, pada tahap inilah para penafsir menemukan hakikat ajaran-ajaran yang memaksa dan juga menemukan realitas absolut yang menjadi dasar segala kenyataan yang ada (Adian, 2012).

\section{Gambaran Jalan Menuju Realitas Metafisik Dalam Perspektif Agama-Agama.}

Dalam perspektif agama-agama, dasar dari segala realitas adalah Tuhan. Agama-agama memberikan gambaran tentang kemungkinan manusia mengetahui Tuhan. Dalam Islam kemungkinan menggapai realitas Ilahi dicapai oleh manusia melalui proses tajalli atau limpahan cahaya sebagaimana dideskripsikan Q.S. Annur: 35, "Cahaya diatas cahaya. Allah mengkaruniakan cahayaNya kepada siapa yang dikehendakiNya”. Dengan limpahan cahaya tersebut, manusia dapat mengungkap rahasia-rahasia yang ada pada Tuhan. Terungkapnya wujud Tuhan sebagai akibat limpahan cahayaNya ini dalam Islam disebut ma'rifah, atau gnosis dalam istilah barat.Alat ma'rifah itu sendiri adalah qalb. Qalb yang telah disinari cahaya Tuhan adalah qalb yang telah dibersihkan dari dosadosa. Pembersihan dosa tersebut dilalui melalui proses takhalli, tahalli, dan tajalli.Takhalli adalah tahap pertaubatan, dimana subjek mengosongkan diri dari maksiat dan sifat-sifat tercela. Tahalli adalah kelanjutantakhalliyaitu tahap dimana subjek mengisi diri dengan akhlak mulia dan ibadah.Tahap ketiga adalah tajalli, yaitu terbukanya 
hijab, sehinggah tampak jelas cahaya Tuhan. Proses tajalli ini disebut dalam Q.s Al-A'raf, 7:143 dengan redaksi berikut: "Tak kala Tuhan tampak bagi gunung itu, kejadian itu menjadikan gunung itu hancur, dan Musa jatuh pingsang”. Dalam Islam, ma'rifah sebagai metode mengenal Tuhan telah lama dikembangkan oleh Al-Gazali dan Zun Al-Nun al Misri sebagaimana yang dapat djumpai dalam literaturliteratur tasawuf (Nata, 2012).

Dalam agama Hindu, realitas dasar itu adalah satu yaitu Brahman. Segala yang berupa fakta-fakta indra adalah maya atau tipuan belaka (Suseno, 2006). Monisme adalah corak yang paling dominan dalam semua filsafat hindu(Bakker, 1991). Kebenaran dalam agama hindu berbeda dengan kebenaran dalam filsafat barat. Bila dalam filsafat barat kebenaran dimaknai sebagai korespondensi antara pengetahuan dan kenyataan, maka dalam filsafat Hindu kebenaran adalah keselamatan(Snijders, 2006). Manusia akan selamat bila ia bersatu denganBrahmanyangmerupakan tujuan akhir. Bersatunya jiwa dengan Brahman hanya mungkin terjadi bila manusia telah mensucikan jiwanya. Pada saat manusia telah terbebas dari nafsunya, ini berarti ia telah terlepas dari materi, sehingga ia mendapatkan ketenangan, dan pada saat itulah manusia telah menyatu dengan Brahman (Al-Maghlouth, 2011). Ada banyak jalan untuk mencapai pengetahuan yang benar dan membebaskan, diantaranya adalah yoga. Selain yoga terdapat pula jalan menuju pelepasan yang terdiri dari: jnana marga, yaitu jalan pelepasan melalui pengetahuan. Manusia akan mendapatkan kelepasan bila ia telah sampai pada pengetahuan bahwa atman adalah Brahman). Karma marga, yaitu jalan pelepasan dengan amal. Bhakti marga adalah kelepasan melalui bhakti atau penyembahan kepada Tuhan (Snijders, 2006). Pengetahun tentang Tuhan sebagai realitas metafisik dalam agama Hindu dicapai melalui proses penyucian jiwa. Hal ini sama dengan tajalli dalam Islam yang juga dilalui dengan cara proses pengosongan sifat-sifat tercela dalam diri manusia.

Berbeda dengan Islam dan Hindu, agama Budha tidak menyebut Tuhan sebagai realitas ultima. Hal ini bukan berarti Budhisme ateis, namun lebih memilih diam ketika berbicara soal ketuhanan (Suseno, 2006). Metafisika Budha nondual tanpa nama dan bentuk dan tidak lahir. Manusia berusaha menjadi bodhisattva dalam kesatuannya dengan Budha (Bakker, 1991). Dalam agama budha realitas terakhir disebut nirvana atau penerangan. Setiap orang 
yang diterangi akan menyatu dengan dengan kenyataan mutlak. Magga adalah jalan menuju kebenaran.Magga terdiri dari delapan jalan: kepercayaan yang benar, keputusan yang benar, perbuatan yang benar, hidup yang benar, usaha yang benar, ingatan yang benar, pemerenungan yang benar. Jalan-jalan ini, adalah jalan yang ditempuh untuk menghilangkan penderitaan dalam rangka mencapai Nirvana.

\section{Simpulan}

Keraguan Immanuel Kant tentang kemungkinan mengetahui realitas metafisik adalah bersandar pada hasil peneyelidikannya tehadap akal manusia yang kemudian ditulisnya dalam Critique of Pure Reason.Setiap pengetahuan ilmiah menurut Kant selalu terdiri dari unsur pengalaman dan rasio.Unsur-unsur yang berasal dari rasio bersifat tetap dan umum yakni berupa kategori-kategori. Sedangkan unsur yang datang dari panca indraberupa kesan-kesan selalu berubah dan individual. Realitasdas ding an sich atau realitas pada dirinya sendiri tidaklah mungkin dicapai oleh manusia, karena kenyataan semacam itu menurut Kant diluar tapal batas nalar manusia sehinggapengetahuan manusia terkurung didalamnya.

Implikasi pandangan Kant tersebut membawa kepada pencarian metode lain yang memungkinkan manusia dapat mengenal realitas pada dirinya sendiri atau dunia nomenanya Immanuel Kant. Metode baru tersebut penting ditemukan sebagai usaha menjawab pertanyaan tentang ada sebagaimana adanya yang telah berlangsung beribu-ribu tahun lamanya, sejak Thales hingga dewasa ini.Sebab jika tidak, maka manusia akan terjebak pada kebisuan dan tenggelam dalam rasa kepenasaran.

Agama adalah sebuah jalan sebagai alternatif memahami realitas metafisik. Agama dengan metodenya sendiri telah diyakini dan dipraktikkan oleh para pemeluknya sebagai salah satu bentuk epistemologi memahami metafisika. Dalam Islam metode itu berupa tasawuf melalui proses takhalli, tahalli dan tajalli. Yoga dalam Budha dan magga dalam agama hindu.

Agama (wahyu) adalah pengetahuan yang diberikan Tuhan sebagai akibat aktivitas refleksi fiosofis. Wahyu tentu saja tidak diberikan kepada setiap orang. Hanya orang-orang yang sungguh sungguh menginginkan kebenaran yang mendapatkannya. Ada dua 
tipe pewahyuan, yaitu wahyu umum yang berupa alam semesta. Tipe ini adalah sebagai cara Tuhan menyapa manusia didunia. Yang kedua adalah wahyu khusus yang berupa pengalaman personal pribadi tertentu. Wahyu khusus merupakan pengalaman religius yang direkam oleh jiwa nabi dan kemudian terdokumentasikan dalam bentuk kitab suci. Pada level ini wahyu pada agama-agama menjadi semacam epsitemologi dalam menjelaskan realitas metafisik. Dari uarain-uraian sebelumnya dapat dikatakan bahwa dunia nomena yang didalamnya termasuk persoalan ketuhanan dapat dikekati dengan cara lain yaitu melalui agama. Agama menjelaskan persoalan-persoalan metafisik yang dalam nalar manusia terkadang dinafikan. Agama memberikan gambaran utuh mengenai metafisika. 


\section{DAFTAR PUSTAKA}

Adian, D. G. 2012. Senjakala Metafisika Barat: dari Humu hingga Heidegger. Depok: Koekoesan.

Al-Maghlouth, S. bin A. 2011. Atlas Agama-Agama: Mengantar Setiap Orang Beragama Lebih Memahami Agama MasingMasing. Almahirah.

Bagus, L. 1991. METFISIKA. Jakarta: PT Gramedia Pustaka Utama. Bakker, A. 1991. Ontologi Metafisika Umum Fislasafat PEngada dan Dasar-Dasar Kenyataan. Yogyakarta: Kanisius.

Bartolomeus Samho, D. 2019. Agama dan Kesadaran Kontemporer. Yogyakarta: Kanisius.

Harun Hadiwijono. 2008. Agama Hindu dan Budha. Jakarta: Gunung Mulia.

Mulyono Slamet Subekti. 2016. Sejarah Pemikiran Moderen. Universitas Terbuka.

Muthmainnah, L. 2018. Tinjauan Kritis Terhadap Epistemologi Immanuel Kant (1724-1804). Jurnal Filsafat, 28(1), 74. https://doi.org/10.22146/jf.31549

Nasution, H. 1975. Filsafat Agama. Jakarta: Bulan Bintang.

Nasution, S. 2013. Sejarah Peradaban Islam. Riau: Yayasan Pustaka Riau.

Nata, A. 2012. Akhlak Tasawuf. Jakarta: Rajawali Pers.

Palmquist, S. 2007. Pohon Filsafat, Teks Kuliah Pengantar FIlsafat. Yogyakarta.

Reza. 2010. Filsafat Kritis Immanuel Kant. Retrieved from www.evolitera.co.id

Snijder, A. 2009. Seluas Segala Kenyataan. In Kanisius. Yogyakarta.

Snijders, A. 2006. Manusia dan Kebenaran. Yogyakarta: Kanisius.

Sumaryono. 1999. Hermeneutika sebagai Metode Filsafat. Yogyakarta.

Suseno, F. M. 2006. Menalar Tuhan. Yogyakarta: Kanisius.

Wijaya, A. 2016. Nalar Epistemologi Agama: Argumen Pluralisme Religius Epistemologis Abdul Karim Sorosh. Epistemé: Jurnal Pengembangan Ilmu Keislaman, 11(2), 201-224. https://doi.org/10.21274/epis.2016.11.2.201-224 